Leadership: Jurnal mahasiswa manajemen Pendidikan Islam

ISSN (P): 2721-7108, ISSN (E): 2715-0399

DOI : http://dx.doi.org/10.32478/leadership. v3i1.882

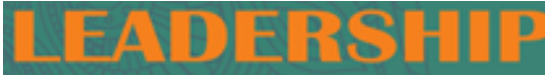

Article Type : Original Research Article

\title{
Perencanaan Manajemen Sarana Dan Prasarana Di Sekolah Dasar Islam Mohammad Hatta Malang
}

\author{
Zakiyah Alvi Rochmania \\ STAI Ma'had Aly Al-Hikam Malang
}

Corresponding author: Email: zakiyahalfi14@gmail.com

Submission Track:

Submisson : :04-01-2022

Accept Submission : 04-01-2022

Avaliable Online : :04-01-2022

Copyright @ 2022 Author

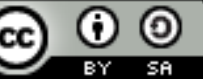

This work is licensed under a Creative Commons Attribution-ShareAlike 4.0

\begin{abstract}
Management as a tool to assist in any activity, such as in the world of education, as the elements contained in management, namely: planning, organizing, implementing, and evaluating. The existence of a management refers more to certain fields, for example in the management of facilities and infrastructure. Management of facilities and infrastructure that regulates facilities and support for school residents to carry out teaching and learning activities. Meanwhile, the facilities and infrastructure before the pandemic and when the pandemic still existed, must have experienced differences. Good facilities and infrastructure need to be prioritized with a plan, planning contained in the management of facilities and infrastructure has one point, namely the existence of a RKAS. RKAS is a plan regarding funds that will be used for school development.
\end{abstract}

Keywords: Facility and Infrastructure Management Planning, RKAS.

\begin{abstract}
Abstrak
Manajemen sebagai alat untuk membantu dalam kegiatan apapun, seperti halnya yang ada di dunia pendidikan, sebagaimana unsur yang terdapat dalam manajemen yakni : perencanaan, pengorganisasian, pelaksanaan, dan evaluasi. Adanya sebuah manajemen lebih mengacu terhadap bidang-bidang tertentu
\end{abstract}


Leadership: Jurnal mahasiswa manajemen pendidikan Islam

ISSN (P): 2721-7108, ISSN (E): 2715-0399

Vol. 03 No. 01 bulan Desember 2021

misalnya terdapat pada manajemen sarana dan prsarana. Manajemen sarana dan prasarana yang mengatur mengenai fasilitas dan penunjang warga sekolah untuk melaksanakan kegiatan belajar dan mengajar. Sedangkan, sarana dan prasarana ketika sebelum pandemi dan ketika pandemi masih ada, pasti mengalami perbedaan. Sarana dan prasarana yang baik perlu didahulukan dengan sebuah perencanaan, perencaan yang terdapat dalam manajemen sarana dan prasarana memiliki salah satu sebuah poin yaitu adanya sebuah RKAS. RKAS merupakan sebuah perencaan mengenai dana yang akan digunakan untuk pengembangan sekolah.

Kata kunci: Perencanaan Manajemen Sarana dan Prasarana, RKAS.

\section{PENDAHULUAN}

Pendidikan adalah tanggung jawab setiap warga negara sebagaimana telah diamanatkan dalam Undang-Undang no 20 tahun 2003, tentang sistem pendidikan nasional pasal 6 ayat 2 yang berbunyi "Setiap warga negara bertanggung jawab terhadap keberlangsungan penyelenggaraan pendidikan". Sehingga dapat dikatakan bahwa pendidikan itu bukan hanya tanggung jawab pemerintah saja, melainkan juga menjadi tanggung jawab masyarakat secara umum. Pendidikan Indonesia sangat menjunjung tinggi mutu yang berkualitas. Hal itu terlihat dalam PP No. 19 tahun 2005 tentang standar nasional pendidikan pasal 3 menyatakan bahwa fungsi dari Standar Nasional Pendidikan adalah sebagai dasar dalam perencanaan, pelaksanaan, dan pengawasan pendidikan dalam rangka mewujudkan pendidikan nasional yang bermutu. Pendidikan yang ada di Indonesia terdapat pendidikan formal maupun pendidikan nonformal. Pendidikan formal dan pendidikan nonformal terimbas dengan dampak covid-19. Salah satunya dengan cara meliburkan kegiatan belajar mengajarnya, seperti lembaga pendidikan nonformal, contohnya TPQ, madrasah diniyah, lembaga bimbingan belajar. Sedangkan kegiatan belajar mengajar yang dilakukan di lembaga formal dilakukan melalui daring atau online. Pendidikan dapat dilakukan dengan berbagai hal, baik media maupun metode yang diajarkan. Sebagaimana pendidikan yang ada saat pandemi covid-19, demi melanjutkan keberhakan dan kewajiban sebagai insan dalam mecari ilmu, maka di masa pandemi pendidikan masih diberlangsungkan meskipun tidak secara tatap muka atau bertemu langsung, melainkan secara virtual atau online atau daring. Bagaimanapun bentuk pendidikan perlu diatur atau di mange, sebagaimana suatu hal apabila diatur terlebi dahulu maka akan berjalan dengan baim dan sedikit mengalami sebuah konflik. Manajemen telah diaplikasikan dalam berbagai hal. Manajemen memiliki empat fungsi yang saling bersinergi apabila saling diterapkan, seperti perencanaan, pengorganisasian, pelaksanaan, dan evaluasi. Fungsi manajemen yang baik akan diterapkan berdasarkan fungsi dan bagian masingmasing bidang yag ada di lembaga pendidikan, seperti halnya, manajemen kurikulum, manajemen kesiswaan, manajemen hubungan masyarakat, manajemen sarana dan prasarana.

Manajemen sarana dan prasarana di lembaga pendidikan sangat penting karena, suatu hal yang menunjang mengenai pembelajaran, salah satu juga sebagai daya tarik antara masyarakat dengan lembaga pendidikan lainnya, dan sebagai lembaga pendidikan yang maju dan bermutu. Meskipun lembaga pendidikan siswa tidak masuk secara langsung, namun di masa pandemi seperti ini tampak sebuah perbedaan dari masa sebelum pandemi, dan masa saat pandemi. Maka dari itu dari adanya sebuah manajemen sarana dan prasarana maka poin penting yang diawal harus ada ialah fungsi manajemen perencanaan. Perencanaan 
manajemen sarana dan prasarana meruapakan langkah awal sebelum dilakukannya sebuah tindakan dalam mengatasi kegiatan belajar mengajar, misalnya dengan merubah rencana awal yang telah disusun sebelumnya dengan beberapa tim, contohnya yang terjadi di dalam RKAS. RKAS telah disusun untuk mengambil langkah ke depannya agar mengurangi resiko yang tidak diinginkan. Namun karena sebuah hal yang tidak disangka dengan adanya sebuah pandemi covid-19 maka perlu perubahan yang bermula di perencanaan sarana dan prasarana.

\section{LITERATUR REVIEW}

\section{A. Manajemen}

Manajemen berasal dari kata to manage yang berarti mengatur, mengurus, dan mengelola. Dengan demikian, makna manajemen mengandung unsur-unsur kegiatan yang bersifat pengelolaan. Malayu S.P Hasibuan menjelaskan bahwa manajemen dalam bahasa Inggris to manage yang artinya mengatur.

Hasibuan menjelaskan bahwa manajemen adalah ilmu dan seni mengatur proses pemanfaatan sumber daya manusia secara efektif, yang didukung oleh sumber-sumber lainnya dalam satu organisasi untuk mencapai tujuan.

Sedangkan para ahli manajemen memberikan pendapat mengenai pengertian manajemen, sebagai berikut:

1) Menurut Marry Marker Follet, manajemen adalah suatu seni, karena untuk melakukan suatu pekerjaan melalui orang lain dibutuhkan keterampilan khusus.

2) Horold Koontz dan Cyril O'Donnel, manajemen adalah usaha untuk mencapai tujuan tertentu melaui kegiatan dengan orng lain.

3) G. R. Terry, manajemen merupakan suatu proses khas yang terdiri oleh tindakan perencanaan, pengorganisasian, penggerakan, dan pengendalian yang dilakukan untuk menentukan serta mencapai sasaran yang telah ditentukan melalui pemanfaatan sumber daya manusia dan sumber daya lainnya.

4) James A. F Stoner mendefinisikan manajemen sebagai proses perencanaan, pengorganisasian, dan penggunaan sumber daya organisasi lainnya agar mencapai tujuan yang akan dicapai.

5) Lawrence A. Appley dan Oey Liang Loe menjelaskan bahwa sebagai seni dan ilmu, dalam manajementerdapat strategi memanfaatkan tenaga dan pikiran orang lain untuk melakukan aktivitas yang diarahkan pada pencapaian tujuan yang telah ditentukan. Dalam manajemen sendiri terdapat teknik-teknik yang kaya dengan nilai-nilai estetika kepemimpinan dalam mengarahkan, mempengaruhi, mengawasi dan mengorganisasikan semua komponen yang dapat menunjang tujuan yang dimaksudkan. ${ }^{1}$

Manajemen terdiri dari empat komponen :

1. Perencanaan

Perencanaan adalah proses dasar dimana manajemen memutuskan tujuan dan cara pencapaiannya². Sedangkan menurut Marno dan Triyo Suproyatno,

\footnotetext{
${ }^{1}$ Beni Ahmad Saebani, Filsafat Manajemen, (Bandung: Pustaka Setia, 2012), hlm. 80.

${ }^{2}$ Iseu Susilawati, dkk, Implementasi Fungsi Manajemen dalam Pelayanan Bimbingan Manasik haji di Kelompok Bimbingan Ibadah Haji, Tadbir: Jurnal Manajemen Dakwah, Vol. 1 No. 2. 2016. hlm. 198.
} 
Leadership: Jurnal mahasiswa manajemen pendidikan Islam

ISSN (P): 2721-7108, ISSN (E): 2715-0399

Vol. 03 No. 01 bulan Desember 2021

perencanaan merupakan salah satu hal yang penting maka perlu dibuat untuk setiap usaha dalam rangka mencapai tujuan.

Alasan pentingnya sebuah perencanaan:

a. Dengan adanya sebuah perencanaan diharapkan dapat menumbuhkan suatu kegiatan yang berupa pengarahan, adanya sebuah pedoman bagi pelaksanaan kegiatan yang ditujukan kepada pencapaian tujuan.

b. Dengan adanya sebuah perencaan maka dapat dilakukan sebuah perkiraan terhadap hal-hal yang akan dilkukan.

c. Perencanaan memberikan kesempatan untuk memilih berbagai alternatif tentang cara terbaik atau kesempatan untuk memilih kombinasi langkah yang terbaik.

d. Dengan perencanaan dapat dilakukan penyusunan skala prioritas.

e. Dengan adanya rencana maka akan ada suatu alat ukur atau standar untuk mengadakan pengawasan dan evaluasi kerja yang telah dilakukan ${ }^{3}$.

2. Pengorganisasian

Pengorganisasian adalah keseluruhan proses pengelompokkan orang-orang, alat-alat, dan tugas serta tanggung jawab dan wewenang sedemikian rupa sehingga tercipta suatu organisasi yang dapat digerakkan sebagai satu keseluruhan dalam rangka mencapai tujuan yang telah ditentukan. ${ }^{4}$

Menurut Hikmat, dalam menjalankan tugas pengorganisasian, terdapat beberapa hal yang diperhatikan oleh pimpinan organisasi, yaitu:

a. Menyediakan fasilitas, perlengkapan, dan staf yang diperlukan untuk melaksanakan rencana.

b. Mengelompokkan dan membagi kerja menjadi struktur organisasi yang teratur.

c. Membentuk struktur kewenangan dan mekanisme koordinasi.

d. Menentukan metode kerja dan prosedurnya.

e. Memilih, melatih, dan memberi informasi kepada staf. ${ }^{5}$

3. Pelaksanaan

Dalam pelaksanaan memiliki hal-hal sebagai berikut:

a. Penetapan start pelaksanaan rencana kegiatan.

b. Pemberian contoh tata cara pelaksanaan kerja dari pemimpin.

c. Pemberian motiavasi terhadap para pekerja agar segera untuk bekerja sesuai dengan tugas dan tanggung jawab masing-masing.

d. Pembinanaan para pekerja.

e. Peningkatan mutu dan kualitas kerja.

f. Pengawasan kinerja dan moralitas pekerja. ${ }^{6}$

4. Evaluasi

\footnotetext{
${ }^{3}$ Muhammad Sahnan, Urgensi Perencanaan Pendidikan di Sekolah Dasar, Jurnal PPKn dan Hukum, Vol. 12 No. 2. 2017 hlm, 144

${ }^{4}$ Ahmad Yusuf Sobri, Manajemen Pendidikan Karakter Berbasis Religi di Sekolah Dasar, 24 No.1, 2015 , hlm. 24

${ }^{5}$ Fathul Maujud, "Implementasi Fungsi-Fungsi Manajemen dalam Lembaga Pendidikan Islam (studi Kasus Pengelolaan Madrasah Ibtidaiyah Islahul Muta'alim Pagutan)”, Jurnal Penelitian Keislaman, Vol.14 No.1, 2018, Hlm. 34.

${ }^{6}$ Beni Ahmad Saebani, Filsafat Manajemen, (Bandung: Pustaka Setia, 2012), hlm. 217.
} 
Evaluasi atau penilaian atau pengawasa ialah pembuatan pertimbangan menurut suatu peringkat kriteria yang disepakati dan dapat dipertanggungjawabkan ${ }^{7}$. Menurut saefullah bahwa conrolling yaitu meneliti dan mengawasi agar semua tugas dilakukan dengan baik dan sesuai dengan peraturan yang ada sesuai dengan deskripsi keja masing-masing personal. ${ }^{8}$ Fungsi pengawasan yang baik yaitu memastikan bahwa sebuah pekerjaan dapat diselamatkan dari kegagalan, sebelum hal tersebut benarbenar terjadi maka pimpinan harus memastikannya lewat pengawasaan yang ketat. Dengannya, pimpinan dapat mengukur ketercapaian suatu program baik dari sisi kuantitas pencapaiannya maupun kualitasnya. ${ }^{9}$

\section{B. Manajemen Sarana dan Prasarana}

Manajemen sarana dan prasarana pendidikan adalah segenap pengaturan mengenai sarana dan prasarana yang dimiliki oleh lembaga pendidikan, dan pengaturan yang dimiliki oleh lembaga pendidikan, dan pengaturan dilakukan dengan melalui proses dan diatur berdasarkan urutan dan fungsi-fungsi manajemen ${ }^{10}$. Manajemen sarana dan prasarana pendidikan adalah seluruh proses kegiatan yang direncanakan dan diusahakan secara sengaja dan serius serta pembinaan secara kontinu terhadap benda-benda pendidikan, agar senantiasa siap pakai dalam proses pembelajaran. ${ }^{11}$

Menurut Depdiknas, sarana adalah semua perangkat peralatan, bahan dan perabotan yang secara langsung digunakan dalam proses pendidikan di sekolah. Sedangkan prasarana adalah perangkat kelengkapan dasar yang secara tidak langsung digunakan menunjang pelaksanaan proses pendidikan di sekolah. Sebagaimana yang telah ditetapkan dalam UU SISDIKNAS No. 20 tahun 2003 Bab XII pasal 45 ayat 1 dijelaskan bahwa : "Setiap satuan pendidikan dan nonformal menyediakan sarana dan prasarana yang memenuhi keperluan pendidikan sesuai dengan pertumbuhan dan perkembangan potensi fisik, kecerdasan intelektual, sosial, emosional dan kejiwaan peserta didik"12. Sedangkan Peraturan Pemerintah Republik Indonesia No. 19 tahun 2005 tentang Standar Nasional Pendidikan yang menyangkut standar sarana dan prasarana pendidikan secara nasional Bab VII pasal 42 dengan tegas disebutkan bahwa: 1) setiap satuan pendidikan wajib memiliki sarana yang meliputi perabot, peralatan pendidikan, media pendidikan, buku dan sumber belajar lainnya, bahan habis pakai, serta pelengkapan lain yang diperlukan untuk menunjang proses pembelajaran yang teratur dan berkelanjutan. 2) Setiap satuan pendidikan wajib memiliki prasarana yang meliputi lahan, runag kelas, ruang pimpinan satuan pendidikan, ruang pendidik, ruang tata usaha, ruang perpustakaan, ruang laboratorium, ruang bengkel kerja, ruang uni produksi, ruang kantin,

7 Ahmad Yusuf Sobri, "Manajemen Pendidikan Karakter Berbasis Religi Di Sekolah Dasar", 24 No. 1, 2015, hlm. 24.

${ }^{8}$ Fathul Maujud, Implementasi fungsi-fungsi manajemen dalam Lembaga Pendidikan Islam (Studi Kasus Pengelolaan Madrasah Ibtidaiyah Islahul Muta'aliman Pagutan), Jurnal Penelitian Keislaman, Vol. 14, No.1, 2018, Hlm. 46.

${ }^{9}$ Fathul Maujud, "Implementasi Fungsi-Fungsi Manajemen dalam Lembaga Pendidikan Islam (studi Kasus Pengelolaan Madrasah Ibtidaiyah Islahul Muta'alim Pagutan)”, Jurnal Penelitian Keislaman, Vol.14 No.1, 2018, Hlm. 35.

${ }^{10}$ Aswin Bancin dan Wildansyah Lubis, Manajemen Sarana dan Prasarana Pendidikan, (Studi Kasus SMA Negeri 2 Lupuk Pakam), Educandu, Vol. 10,No. 1, 2017, hlm. 67.

${ }^{11}$ Sri Setyaningsih, "Pengelolaan Sarana Prasarana dalam Implementasi Kurikulum Pendidikan Guru Sekolah Dasar”, Jurnal Manajemen Pendidikan, Vol. 13, No. 1, 2018, hlm. 66.

${ }^{12}$ Devi Dwi Sylviani, "Kondisi Sarana dan Prasarana Pendidikan SMP Negeri Se-Kecamatan Pengasih Kabupaten Kulon Progo", (2018), hlm. 4. 
instalasi daya dan jasa, tempat berolahraga, tempat beribadah, tempat rekreasi, dan ruang atau tempat lain yang diperlukan untuk menunjang proses pembelajaran yang teratur dan berkalanjutan. ${ }^{13}$.

Ditinjau dari fungsi atau perannya terhadap pelaksanaan proses belajar mengajar, maka sarana pendidikan dibagi menjadi dua macam yaitu alat palajaran dan media pendidikan. Alat pelajaran adalah alat atau benda yang secara langsung digunakan oleh guru dan murid untuk pembelajaran. Alat pembelajaran terdiri dari (1) Buku-buku (2) Kamus, Kitab Al-Qur'an (3) Alat-alat peraga (4) Alat-alat praktek (5) Alat tulis menulis. Nasional Education Assosiation menyatakan media adalah bentuk-bentuk komunikasi baik tercetak maupun audiovisual serta peralatannya. Sedangkan prasarana pendidikan dibedakan menjadi dua yaitu bangunan sekolah dan perabot sekolah. Bangunan sekolah terdiri dari ruang teori, ruang administrasi atau kantor, ruang penunjang, prasarana lingkungan atau infrastruktur, perabot Sekolah atau Madrasah ${ }^{14}$. Standar prasarana pendidikan mencakup persyaratan minimal dan wajib dimiliki oleh setiap satuan pendidikan. Lahan yang dimiliki setidaknya meliputi: ruang kelas, ruang pimpinan, ruang pendidik, ruang tata usaha, ruang perpustakaan, ruang laboratorium, ruang bengkel kerja/praktik, ruang unit produksi, ruang kantin, instalasi daya dan jasa, tempat berolahraga, tempat beribadah, tempat bermain, tempat berkreasi, dan ruang/tempat lain untuk menunjang proses pembelajaran yang teratur dan berkelanjutan. Standar sarana pendidikan mencakup persyaratan minimal tentang perabot, peralatan pendidikan, media pendidikan, buku dan sumber belajar lainnya, bahan habis pakai, serta perlengkapan lain yang diperlukan untuk menunjang proses pembelajaran yang teratur dan berkelanjutan (Depdiknas, 2006). ${ }^{15}$

Secara lebih rinci Tim Pakar Manajemen Universitas Negeri Malang mengidentifikasi beberapa hal mengenai tujuan sarana dan prasarana pendidikan yaitu:

a. Untuk mengupayakan pengadaan sarana dan prasarana pendidikan melalui sistem perencanaan dan Pengadaan secara hati-hati dan seksama, sehingga sekolah atau madrasah memiliki sarana dan prasarana yang baik sesuai dengan kebutuhan dana yang efisien.

b. Untuk mengupayakan pemakaian sarana dan prasarana sekolah itu harus secara tepat dan efisien.

c. Untuk mengupayakan pemeliharaan sarana dan prasarana pendidikana secara teliti dan tepat, sehingga keberadaan sarana dan prasarana tersebut akan selalu dalam keadaan siap pakai ketika akan digunakan atau diperlukan. ${ }^{16}$

Manajemen sarana dan prasarana memiliki beberapa proses yang meliputi perencanaan, pengadaan, pengaturan, penggunaan dan penghapusan ${ }^{17}$. Kelima proses tersebut dipadukan dan membentuk siklus seperti gambar di bawah ini.

\footnotetext{
${ }^{13}$ Desi Nurhikmahyanti, “Manajemen Sarana Prasarana Pendidikan Di Sma Negeri 1 Driyorejo Gresik", Hlm. 3

${ }^{14}$ Tubagus Djaber Abeng Ellong, "Manajemen Sarana Dan Prasarana di Lembaga Pendidikan Islam, Jurnal Pendidikan Islam Iqra' ', Vol. 11. Nomor 1, hlm. 3.

${ }^{15}$ Sri Setyaningih, "Pengelolaan Sarana Prasarana dalam Implementasi Kurikulum Pendidikan Guru Sekolah Dasar: Sebuah Studi Kasus di Universitas Negeri Semarang”, Jurnal Managemen Pendidikan, Vol. 13, No. 1, 2018, Hlm. 67.

${ }^{16}$ Ibid.., hlm. 4.

${ }^{17}$ Barnawi dan M. Arifin, Manajemen Sarana dan Prasarana Sekolah (Jogjakarta: Ar-Ruzz Media, 2012), hlm 15
} 


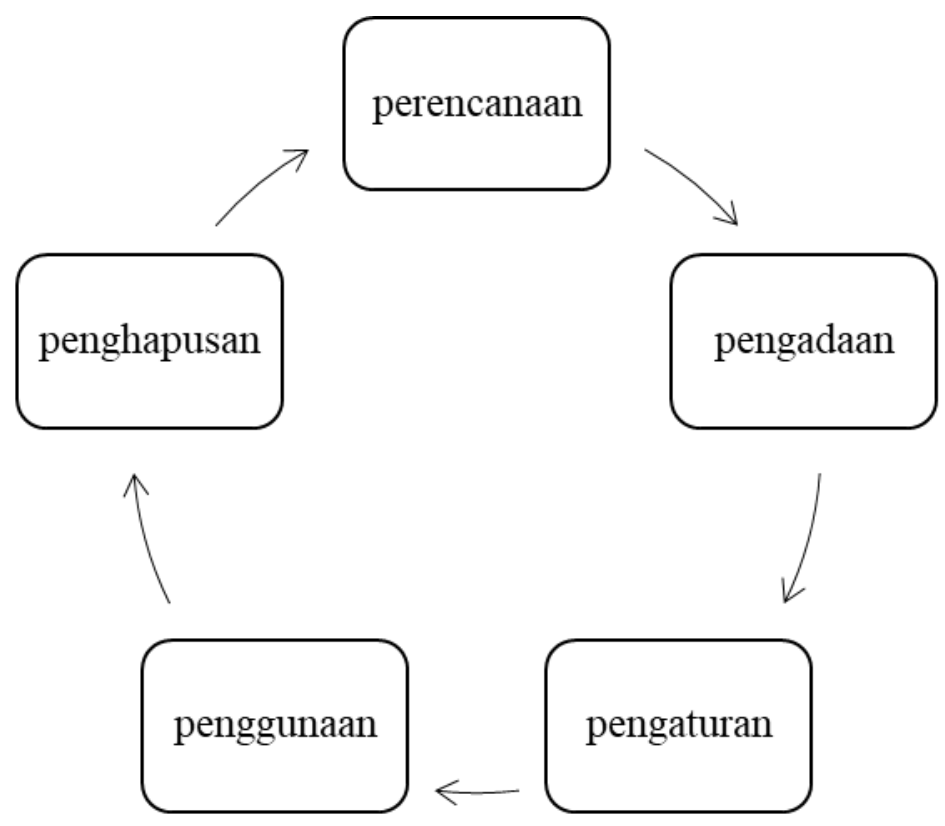

\section{Perencanaan}

Perencanaan sarana dan prasarana pendidikan pertama melalui analisis kebutuhan dilakukan dengan menganalisis dan mengevaluasi sarana dan prasarana apa saja yang diperlukan untuk mendukung proses pembelajaran di dalam kelas maupun di luar kelas. Kegiatana analisis sarana dan prasarana pendidikan melibatkan guru kelas maupun guru mata pelajaran, akan tetapi peranan guru kelas dalam menganalisis kebutuhan lebih besar tanggung jawabnya daripada guru mata pelajaran.

\section{2. pengadaan}

Pengadaan sarana dan prasarana pendidikan yang pertama adalah penetapan, penetapan dilakukan bersama-sama dengan semua pihak sekolah mengacu pada kebutuhan yang sangat penting untuk mendukung proses pembelajaran. Hal tersebut didukung oleh Ihuoma intinya menyatakan bahwa dalam penetapan sarana dan prasarana mengacu pada suatu tujuan diadakannya sarana dan prasarana tersebut. Tujuan utama dalam penetapan untuk memenuhi kebutuhan proses pembelajaran di dalam kelas. ${ }^{18}$

3. Pengaturan

Pengaturan terhadap sarana dan prasarana ini dapat dicontohkan dengan pemberian nomer inventaris.

\section{Penggunaan}

Menurut Barnawi hal-hal yang perlu diperhatikan dalam penggunaan sarana prasarana, sebagai berikut:

a. Penyusunan jadwal penggunaan harus dihindari benturan dengan kelompok lain.

b. Hendaknya kegiatan-kegiatan pokok sekolah merupakan prioritas utama.

${ }^{18}$ Nasrudin dan Maryadi, "Manajemen Sarana Dan Prasarana Pendidikan dalam Pembelajaran di SD, Jurnal Managemen Pendidikan”, Vol. 13, No. 1, 2018, Hlm. 19. 
Leadership: Jurnal mahasiswa manajemen pendidikan Islam

ISSN (P): 2721-7108, ISSN (E): 2715-0399

Vol. 03 No. 01 bulan Desember 2021

c. Waktu/jadwal penggunaan hendaknya diajukan pada awal tahun ajaran.

d. Penugasan/penunjukan personel sesuai dengan keahlian pada bidangnya, misalnya petugas laboratorium, perpustakaan, operator, komputer dan sebagainya.

e. Penjadwalan dalam penggunaan sarana prasarana sekolah, antara kegiatan intrakulikuler dengan ekstrakulikuler harus jelas. ${ }^{19}$

\section{Penghapusan}

Penghapusan sarana prasarana Menurut Minarti penghapusan adalah kegiatan meniadakan barang-barang milik lembaga dari daftar inventaris berdasarkan peraturan perundang-undangan dan pedoman yang berlaku. Adapun tujuan penghapusan barang, yaitu mencegah atau membatasi kerugian terhadadanap barang yang memerlukan dan pengaman dana besar dalam pemeliharan, mencegah terjadinya pemborosan biaya pengamanan perlengkapan yang tidak berguna lagi, membebaskan lembaga dari tanggubng jawab pemeliharaan dan pengamanan, serta meringankan beban inventarisasi. ${ }^{20}$

\section{Perencanaan Manajemen Sarana dan Prasarana}

Perencanaan sarana prasarana merupakan salah satu tindakan yang amat penting dalam proses mempersiapkan seperangkat keputusan mengenai tindakan yang akan dilakukan pada suatu kurun waktu tertentu dan mengenai cara melaksanakannya untuk mencapai tujuan tertentu, dalam hal ini, perencanaan yang dimksud adalah merinci rancangan pembelian, pengadaan, rehabilitasi, distribusi atau pembuatan peralatan, dan perlengkapan sesuai denagn kebutuhan. Tujuan yang diungkapkan oleh Minarti bahwa tujuan perencanaan tersebut yaitu: a) untuk mengupayakan pengadaan sarana prasarana pendidikan melalui sistem perencanaan dan pengadaan yang hati-hati dan seksama. b) Untuk mengupayakan pemakaian sarana prasarana secaratepat dan efisien. c) Untuk mengupayakan pemeliharaan sarana dan prasarana sehingga keberadaannya selaludalam kondisi siap pakai dalam setiap saat. ${ }^{21}$

Ada dua hal penting yang harus dilakukan ketika merencanakan kebutuhan sarana dan prasarana pendidikan, kedua hal tersebut ialah menganalisis kebutuhan sarana dan prasarana yang ada, dan memproyeksi sarana dan prasarana yang dibutuhkan di masa depan. $^{22}$

1. Menganalisis kebutuhan sarana dan prasarana yang ada.

Untuk mengetahui kebutuhan sarana dan prasarana pendidikan pada suatu unit diperlukan data dan informasi baik itu berupa yang ada di lapangan maupun yang seharusna ada sesuai ketentuanyang berlaku. Analisis merupakan kegiatan membandingkan antara data yang ada di lingkungan dengan data yang seharusnya ada menurut pembakuan sarana dan prasarana pendidikan. Hasil analisis akan bertumpu pada dua informasi, yaitu informasi tentang kesesuaian dan tidak ada kesesuaian. Jika analisis menghasilkan informasi tidak ada kesesuaian maka ada dua

\footnotetext{
${ }^{19}$ Aswin Bancin dan Wildansyah Lubis Manajemen Sarana Dan Prasarana Pendidikan (Studi Kasus SMA Negeri 2 Lupuk Pakam)”, EducanduM, Volume: X, No. 1, Hlm. 68.

${ }^{20}$ Desi Nurhikmahyanti, "Manajemen Sarana Prasarana Pendidikan di SMA Negeri 1 Driyorejo Gresik”, Hlm. 5.

${ }^{21}$ Desi Nurhikmahyanti, “Manajemen Sarana Prasarana Pendidikan Di SMA Negeri 1 Driyorejo Gresik”, Hlm. 3.

${ }^{22}$ Matin dan Nurhattati, "Manajemen Sarana dan Prasarana Pendidikan: Konsep dan Aplikasinya”, (Depok: PT Rajagrafindo Persada, 2017), hlm. 7.
} 
Leadership: Jurnal mahasiswa manajemen pendidikan Islam

ISSN (P): 2721-7108, ISSN (E): 2715-0399

Vol. 03 No. 01 bulan Desember 2021

kemungkinan yaitu sarana dan prasarana keadaannya kurang atau keadaannya berlebih. Jika keberadaan sarana dan prasarana

2. memproyeksi sarana dan prasarana yang dibutuhkan di masa depan.

Perencanaan sarana dan prasarana pendidikan juga dapat dilakukan berdasarkan data masa yang akan datang sebagai hasil proyeksi. Proyeksi kebutuhan sarana dan prasarana pendidikan di masa depan mencangkup berbagai pertimbangan. Mungkin membutuhkan keahlian teknik yang tinggi di luar kemampuan ahli perencana pendidikan untuk mengetahui informasi apa saja yang dibutuhkan dalam rangka pembangunan untuk mengkontruksi gedung sekolah dan sarana lainnya.

Hal ini berkaiatan langsusng dengan informaasi fasilitas sekolah untuk dikumpulkan dan disediakan untuk pelayanan secara langsung kepada perencana, perumus pembiayaan, dan pengkontruksi fasilitas sekolah. Tugas pertama perencana dalam hal ini adalah mengumpulkan data untuk menentukan persediaan sarana pendidikan yang ada saat ini berdasarkan jenis dan jenjang pendidikan, termasuk bagaimana kualitasnya. Untuk itu, perencaan dapat melakukan pendidikan yang ada di sekolah-sekolah. Data hasil survei tersebut kemudian dibandingkan dengan ketentuan atau standar-standar yang sudah ditentukan guna memperoleh informasi yang ada di sekolah-sekolah tersebut kondisinya baik atau buruk.Proyeksi kebutuhan sarana dan prasarana pendidikan harus dilakukan guna menampung penduduk usia sekolah yang bertambah setiap tahun dan diperkirakan bertambah menurut perhitungan proyeksi penduduk dan proyeksi siswa. Proyeksi kebutuhan sarana pendidikan dalam hal ini masih bersifat garis besar yang harus dirinci lebih lanjut berdasarkan standar minialsarana sekolah yang berlaku pada suatu negara atau suatu wilayah tertentu. Eliot dan Mosier menyatakan bahwa secara umum tahapan-tahapan secara dalam proses perencanaan adalah :

a. Menetapkan secara sementara tujuan-tujuan didasarkan pada kebutuhan pendidikan.

b. Menetapkan keadaan sekarang dari pendidikan dalam masyarakat tertentu.

c. Merumuskan suatu program khusu tentang tujuan-tujuan bagi sekolah.

d. Menetapkan rangkaian tindakan yang perlu untuk mencapai tujuan-tujuan tersebut.

e. Mewujudkan rencana menjadi tindakan.

f. Mengadakan penilaian secara terus menerus.

g. Merencanakan kembali bilamana penilaian menyatakan ini perlu atau diinginkan ${ }^{23}$

Syarat-syarat dalam menyusun perencanaan meliputi (1) Mengikuti pedoman (standar) jenis, kualitas dan kuantitas sarana dan prasaran sesuai dengan skala prioritas (2) Mengadakan perlengkapan yang diperlukan dengan plafon anggaran (3) Menyediakan dan menggunakan sarana dan prasarana operasional (4) Menyimpan dan memelihara (5) Mengikuti prosedur pengelolaan (6) Perencanaan pengadaan barang bergerak (7) Perencanaan pengadaan barang bergerak habis pakai (8)

${ }^{23}$ E.B. Eliot and E.E. Mossier, "Organization of Planning for Education, dalam American education in the post War Period", NSSE (Chacago: Chicago Press, 1945), hlm. 275-276 
Leadership: Jurnal mahasiswa manajemen pendidikan Islam

ISSN (P): 2721-7108, ISSN (E): 2715-0399

Vol. 03 No. 01 bulan Desember 2021

Perencanaan pengadaan barang tidak bergerak habis pakai (9) Perencanaan pengadaan barang tidak bergerak (10) Perhitungan kebutuhan ruang belajar. ${ }^{24}$

\section{RKAS}

Perencanaan sumber dana tahunan di sekolah/madrasah disebut dengan Rencana Kegiatan dan Anggaran Sekolah (RKAS). Semua sumber dana yang dimiliki dan pembiayaan yang dipakai oleh lembaga direncanakan dalan perencanaan pendidikan jangka pendek atau tahunan yang disebut RKAS ${ }^{25}$

Menurut Undang-Undang No. 20 tahun 2003 tentang Sistem Pendidikan Nasional dalam asal 56 komite sekolah merupakan lembaga mandiri yang berperan dalam meningkatkan mutu dengan memberikan pertimbangan, arahan, dan dukungan tenaga, sarana dan prasarna, serta pengawasan pendidikan pada tingkat satuan pendidikan. ${ }^{26}$

Pemerintah memberikan kebebasan kepada pihak penerima dana BOS untuk melaksanakan pengelolaan dana BOS. Pemberian kebebasan salah satunya adalah penyusunan perencanaan dalam hal ini adalah penyusunan Rencana Kegiatan dan Anggaran Sekolah (RKAS) yang disesuaikan dengan kondisi dan kebutuhan dari masingmasing sekolah penerima dana BOS. ${ }^{27}$

Sarana dan prasarana dalam lembaga pendidikan termasuk juga RKAS sangat penting bagi sekolah, sebagaimana diungkangkan oleh Husaini Usman bahwa perencanaan memiliki manfaat yaitu: sebagai standar pelaksanaan dan pengawasan; sebagai pemilihan beberapa alternatif terbaik; penyusunan skala prioritas baik sasaran maupun kegiatan sekolah; menghemat pemanfaatan sumber daya organisasi; membantu pimpinan untuk menyesuaikan dengan perubahan lingkungan; untuk memudahkan berkoordinasi dengan pihak-pihak terkait; serta meminimalisir pekerjaan yang tidak pasti. Sehingga dari adanya beberapa perencaan terlebih dahulu, sekolah akan lebih mudah dan jelas dalam melaksanakan kegiatan-kegiatan selama tahun ajaran. ${ }^{28}$

\section{METODE PENELITIAN}

Metode penelitian yang digunakan dalam tulisan ini adalah metode deskriptif kualitatif, dengan jenis penelitian kepustakaan (library research). Penelitian pustaka

\footnotetext{
${ }^{24}$ Tubagus Djaber Abeng Ellong, "Manajemen Sarana Dan Prasarana Di Lembaga Pendidikan Islam" jurnal Pendidikan Islam Iqra'. Vol. 11. No. 1. Hlm. 6.

${ }^{25}$ Komang Alit Wahyuni, "Efektivitas Rencana Kegiatan Dan Anggaran Sekolah (Rkas) Pada Kualitas Layanan Pendidikan Smk dan Sma Di Kecamatan Sawan Tahun Ajaran 2013/2014”, Vol: 4 No: 1, 2014, Hlm. 2.

${ }^{26}$ Mashur Riadli, Partisipasi Komite Sekolah Dalam Penyususna Rencana Kegiatan Dan Anggaran Sekolah (Rkas) di SMA Se-Kabupaten Sleman, hlm. 3.

${ }^{27}$ Janan Witanto, Bambang Ismanto, Wasitohadi, "Peningkatan Efektifitas Perencanaan Bantuan Operasional Sekolah Dalam Mendukung Kebutuhan Anggaran Berbasis Mutu Melalui Workshop Di Dabin Iii Kecamatan Mojosongo Kabupaten Boyolali”, Vol 8 No 2, 2019, Jurnal Ilmu Sosial dan Humaniora, hlm. 252.

${ }^{28}$ Mashur Riadli, Partisipasi Komite Sekolah Dalam Penyususna Rencana Kegiatan Dan Anggaran Sekolah (Rkas) di SMA Se-Kabupaten Sleman, hlm. 2.
} 
Leadership: Jurnal mahasiswa manajemen pendidikan Islam

ISSN (P): 2721-7108, ISSN (E): 2715-0399

Vol. 03 No. 01 bulan Desember 2021

merupakan serangk aian kegiatan yang berkenaan dengan metode pengumupulan data pustaka, membaca dan mencatat serta mengolah bahan penelitian. Rangka penelitian dilakukan secara beberapa tahapan, yaitu menelusuri mencatat dan membaca artikel sesuai pembahasan majemen sarana dan prasarana di era pandemi covid-19.

Lokasi penelitian dilakukan di SD Islam Mohammad Hatta Malang yang terletak di Jl. Simpang Flamboyan No. 30 atau Jl. Kamelia no.30 Malang, yang bernaungan di bawah Yayasan Bina Insan Kamil.

\section{HASIL}

\section{A. Gambaran Umum SDI Mohammad Hatta}

1. Profil SD Islam Mohammad Hatta merupakan

a. Propinsi : Jawa Timur

b. Otonomi : Daerah Kota Malang

c. Kecamatan : Lowokwaru

d. Kelurahan : Lowokwaru

e. Kabupaten/Kota : Malang

f. Alamat : Jl. Simpang Flamboyan No. 30

g. Kode Pos :65141

h. Telepon :0341-413003

i. Website : www.sdimohhattamalang.com

j. Daerah : Perkotaan

k. Status sekolah : Swasta

I. Kelompok Sekolah : Imbas Gugus $1 \mathrm{Kec}$. Lowokwaru

m. Akreditasi : 4 Tahun (Klasifikasi A)

n. Surat Keputusan : No. Dd. 005223 Tanggal : 210ktober 2009

o. Penerbit SK : Badan Akreditasi Sekolah

/Madrasah ( BAN-S/M)

p. Tahun Berdiri : 2003

q. Kegiatan Belajar Mengajar : Pagi

r. Bangunan Sekolah : Milik Sendiri

s. Luas Bangunan $\quad: 500 \mathrm{M}^{2}$ dari Luas Tanah $2000 \mathrm{M}^{2}$

t. Lokasi Sekolah : Strategis

u. Jarak Ke Pusat Kota $\quad: 4 \mathrm{KM}$

v. Jarak ke Pusat $: 7 \mathrm{KM}$

w. Terletak Pada Lintasan : Kota

x. Organisasi Penyelenggara : Yayasan Bina Insan Kamil Indonesia

2. Visi, Misi dan Tujuan SD Islam Mohammad Hatta

Visi : Meletakkan dasar - dasar pengembangan sumber daya insan yang berkualitas di bidang IPTEK dan IMTAQ.

Misi : Menyelenggarakan pendidikan dasar yang beriorentasi kualitas, baik keilmuan, moral maupun social, berlandasan agama Islam. 
Leadership: Jurnal mahasiswa manajemen pendidikan Islam

ISSN (P): 2721-7108, ISSN (E): 2715-0399

Vol. 03 No. 01 bulan Desember 2021

Tujuan : Memberikan kemampuan baca tulis, hitung pengetahuan dan keterampilan dasar berkehidupan, kemampuan dasar tentang agama Islam dan pengalamannya sesuai dengan ajaran Islam

3. Struktur Organisasi

a. Yayasan Bina Insan Kamil Indonesia

I. Ketua Pembina : Prof. H. Masruchin Ruba'i, SH, MS

Anggota : Ir. H. Marsul Hidayat

II. Pengawas : Prof. Dr. Ir. H. Mochammad Yunus, MS

Anggota $\quad:$ H. Soecipto Abdul Djali

III. Ketua Umum : Prof. H. Bambang Supriyono, MS

IV. Sekretaris : Muhammad Farid, S.Pd

V. Bendahara : Mahda Chaira. S.TP

VI. Tim Pengembang : Dra. Hj. Wajdiyah Abdillah, DR. H. Zulfi Mubarak, MA

b. Komite Sekolah

i. Ketua : Febriyansyah Saltiar.

ii. Sekretaris: Niken

iii. Bendahara : Zulfiska, ST.

c. Pimpinan Sekolah

1) Kepala Sekolah : Suyanto, S.Pd, M.KPd

2) Waka Kurikulum dan Pengajaran : Tomi Ariyansah, S.Pd

3) Waka Sarpras dan Rumah Tangga: Riesda Januarty, S.Pd

4) Waka Kesiswaan dan Kehumasan: Muhammad Farid, S.Pd

B. Perencanaan Manajemen sarana dan prasarana di SDI Mohammad Hatta

Pada kegiatan perencanaan manajemen sarana dan prasarana yang dilakasankan di SDI Mohammad Hatta, terdapat tahap inti yang dilakukan agar dapat memberikan kontribusi yang membangun bagi sekolah tersebut. Waka (wakil kepala sekolah) dibidang sarana dan prasarana, yang dalam hal ini memiliki tanggung jawab dalam keseluruhan kegiatan perencanaan manajemen sarana dan prasarana sehingga akan didapatkan data serta informasi mengenai kebutuhan serta kondisi nyata sarana dan prasarana di sekolah tersebut. Berikut merupakan 2 (dua) tahapan atau proses inti yang dilakukan di SDI Mohammad Hatta dalam rangka perencanaan manajemen sarana dan prasarana, antara lain :

1. Analisis Kebutuhan Sarana dan Prasarana

Perencanaan Manajemen Sarana dan Prasarana

Perencaan selalu ada di awal, maka dari itu kami merencanakan sebelum awal tahun ajaran baru. Pihak perencanaan sarana dan prasarana membentuk tim untuk mengadakan rapat dan menyusun perencanaan sarana dan prasarana, dari situ ada sebuah RKAS, yang mengacu dari data di tahun sebelumnya untuk menganalisis sebuah kebutuhan mencapai tujuan.

2. Proyeksi Kebutuhan Sarana dan Prasarana

Tahap proyeksi sarana dan prasarana yang dilakukan di SDI Mohammad Hatta adanya sebuah hasil dari perencanaan sarana dan prasarana yakni RKAS. RKAS dapat memproyeksi karena mengacu dari data sebelumnya.

RKAS terbagi menjadi 3 macam diantaranya: 
Leadership: Jurnal mahasiswa manajemen pendidikan Islam

ISSN (P): 2721-7108, ISSN (E): 2715-0399

Vol. 03 No. 01 bulan Desember 2021

RPS (Rencana Program Sekolah), yang mana rencana program kerja ini memiliki pandangan ke depan untuk 4 tahun kedepan akan dibawa kemana sekolah untuk menjadi lebih baik.

RJM (Rencana Jangka Menengah) yakni perencanaan yang diakan dibuat untuk per dua tahun;RKT (Rencana Kegiatan Tahunan).

\section{Dana operasional}

Dana operasional adalah dana yang digunakan untuk keperluan sekolah yang berasal dari: (1) pemerintah pusat (BOSNAS) dan (2) pemerintah daerah (BOSDA), serta dana swadaya masyarakat. Sedangkan untuk perencanaan dana yang lainnya yaitu berasal dari masyarakat yang dapat disebut dengan dana swadaya masyarakat. (3) Swadaya masyarakat terbagi menjadi 2: DPP dan SPP;

DPP: dana yang khusus untuk pembagunan sekolah dan pengembangan sumber daya manusia dalam hal ini meliputi profesional (masih akan diadakannya dana pendidikan dan dana pelatihan bagi karyawan) dan spritual (adanya program umroh bagi karyawan).

SPP: SPP mrupakan dana yang digunakan untuk honorium guru dan karyawan. SPP dibayarkan dari wali murid melaui tunai maupun non tunai setiap bulan.

Kendala yang dialami dalam penyusunan RKAS:

1. Mendatangkan komite, orang tua, serta SDM saat penyusunan.

2. Beberapa item yang telah direncakan tidak seusai dengan kenyataan.

3. Dana yang terlambat cair.

\section{PEMBAHASAN}

\section{A. Perencaan Manajemen Sarana dan Prasarana}

Fungsi manajemen sebagai usaha untuk menentukan tujuan yaitu: perencanaan, pengorganisasian, pelaksanaan dan evaluasi. Sebagaimana sebuah kegiatan yang dilakukan selalu didahulukan dengan perencanaan sebagai langkah menuju sebuah tujuan yang akan dicapai. Adanya sebuah perencanaan manajemen sarana dan prasrana sendiri memiliki kemudahan untuk kedepannya dan meminimalisir sebuah kesalahan maupun kerugian yang diperkiran akan dilakukan.

Standar prasarana pendidikan mencakup persyaratan minimal dan wajib dimiliki oleh setiap satuan pendidikan. Lahan yang dimiliki setidaknya meliputi: ruang kelas, ruang pimpinan, ruang pendidik, ruang tata usaha, ruang perpustakaan, ruang laboratorium, ruang bengkel kerja/praktik, ruang unit produksi, ruang kantin, instalasi daya dan jasa, tempat berolahraga, tempat beribadah, tempat bermain, tempat berkreasi, dan ruang/tempat lain untuk menunjang proses pembelajaran yang teratur dan berkelanjutan. Standar sarana pendidikan mencakup persyaratan minimal tentang perabot, peralatan pendidikan, media pendidikan, buku dan sumber belajar lainnya, bahan habis pakai, serta perlengkapan lain yang diperlukan untuk menunjang proses pembelajaran yang teratur dan berkelanjutan (Depdiknas, 2006). ${ }^{29}$ Sebagaiaman standar

${ }^{29}$ Sri Setyaningih, "Pengelolaan Sarana Prasarana dalam Implementasi Kurikulum Pendidikan Guru Sekolah Dasar: Sebuah Studi Kasus di Universitas Negeri Semarang”, Jurnal Managemen Pendidikan, Vol. 13, No. 1, 2018. Hlm. 67. 
prasarana di atas maka yang wajib dan telah dimiliki oleh SD Islam Mohammad Hatta meliputi: (a) ruang kelas (yang terdiri dari kelas 1 sampai kelas 6 yang terdiri dari a, b, dan c); (b) ruang pendidik (sebagai tempat berkumpulnya pendidik biasanya sebagai tempat untuk rapat); (c) ruang tata usaha; (d) ruang perpustakaan; (e) ruang laboratorium yang berupa laboraturium komputer; (f) ruang kantin, yang mana SD Islam mengadakan sebuah kantin kejujuran; (g) tempat berolahraga, salah satu yang dimiliki oleh SD Islam Mohammad Hatta yaitu kolam renang; (h) tempat beribadah, yakni masjid yang sedang ada perenovasian.

Ada dua hal penting yang harus dilakukan ketika merencanakan kebutuhan sarana dan prasarana penndidikan, kedua hal tersebut ialah :

1. Menganalisis kebutuhan sarana dan prasarana yang ada

Sebagaimana dalam perencanaan dalam fungsi manajemen maka perlu dilakukan sebuah analisis untuk melengkapi kegiatan perencanaan. Perencanaan manajemen sarana dan prasarana dengan diadakanya sebuah kegiatan yang berupa rapat, pihak perencanaan sarana dan prasarana membentuk tim untuk mengadakan sebuah rapat dan menyusun perencanaan sarana dan prasarana, dari situ mengahasilkan sebuah RKAS dengan kepala sekolah, komite, wali murid, dan dewan guru, perencanaa sarana dan prasarana dilaksanakan sebelum awal tahun ajaran baru. Menyusun RKAS ini mengacu dari data tahun sebelumnya untuk dianalisis dan dapat ditarik sebuah perencanaan kebutuhan mencapai tujuan yang ditanda tangani oleh kepala sekolah dan bendahara.

2. Memproyeksi sarana dan prasarana yang dibutuhkan di masa depan

Dari hasil rapat yang telah disusun oleh tim perencana manajemen sarana dan prasarana dengan menghasilkan RKAS maka dalam RKAS itu dapat membantu dalam memproyeksi sarana dan prasarana yang dibutuhkan untuk masa depan. Dalam rencana program sekolah mendapati RKAS dan memiliki beberapa bagian perencanaan tahunan yang terdiri dari RKT (Rencana Kerja Tahunan), RJM (Rencana Jangka Menengah), RPS (Rencana Program Sekolah).

Eliot dan Mosier menyatakan bahwa secara umum tahapan-tahapan secara dalam proses perencanaan adalah :

a. Menetapkan secara sementara tujuan-tujuan didasarkan pada kebutuhan pendidikan.

b. Menetapkan keadaan sekarang dari pendidikan dalam masyarakat tertentu.

c. Merumuskan suatu program khusu tentang tujuan-tujuan bagi sekolah.

d. Menetapkan rangkaian tindakan yang perlu untuk mencapai tujuan-tujuan tersebut.

e. Mewujudkan rencana menjadi tindakan.

f. Mengadakan penilaian secara terus menerus.

g.Merencanakan kembali bilamana penilaian menyatakan ini perlu atau diinginkan ${ }^{30}$.

Beberapa tahapan dalam proses perencanaan di atas telah dilaksanakan oleh SD Islam

Mohammad Hatta dengan mengadakan rapat dan menghasilkan sebuah RKAS. Namun dengan keadaan seperti sekarang ini adanya sebuah pandemi covid 19 maka perlu terjadi perubahan seperti adanya pembelian akun zoom, pembelian kamera, serta alat yang menunjang kegiatan belajar mengajar yang dilakukan secara daring, serta beberapa alat sebagai perlengkapan di masa pandemi covid-19 misalnya faceshield, penambahan tempat cuci tangan, pengukur suhu tubuh. Maka dari situ perlu

${ }^{30}$ E.B. Eliot and E.E. Mossier, "Organization of Planning for Education, dalam American education in the post War Period", NSSE (Chacago: Chicago Press, 1945), hlm. 275-276 
Leadership: Jurnal mahasiswa manajemen pendidikan Islam

ISSN (P): 2721-7108, ISSN (E): 2715-0399

Vol. 03 No. 01 bulan Desember 2021

perubahan sebuah RKAS dan pelaporan sesuai dengan keadaan dan kebutuhan yang ada saat pandemi covid-19.

\section{B. RKAS}

1. RKAS

RKAS merupakan Rencana Kegiatan dan Anggaran Sekolah (RKAS) merupakan perencanaan jangka pendek atau perencanaan tahunan yang menggambarkan tujuan yang akan dicapai dalam kurun waktu satu tahun yang memuat delapan (8) standar pendidikan yang tercantum dalam Peraturan Menteri Pendidikan Nasioanl No. 19 Tahun 2007 Tentang Standar Pengelolaan Pendidikan Oleh Satuan Pendidikan Dasar dan Menengah. ${ }^{31}$ Sebagaimana yang terdapat pada SD Islam Mohammad Hatta RKAS kegiatan mengacu pada program kegiatan kepala sekolah. Adanya pembuatan RKAS dari analisis lingkungan dan hasil monitoring atau supervisi tahun kemarin, dianalisis bagaimana keadaan pembelajaran guru-guru bagaimana nanti ada persentasenya dari kegiatan pembelajaran kurikulum. RKAS di SD Islam Mohammad Hatta terbagi menjadi tiga diantaranya: RPS yang mana rencana program kerja ini memiliki pandangan ke depan untuk 4 tahun kedepan agar sekolah menuju menjadi lebih baik. Dari RPS dibagi setiap tahun menjadi RKT, RKT tahun pertama, RKT tahun Kedua dan RKT tahun keempat; sedangkan jika memasuki tahun kedua maka disebut RJM (Rencana Jangka Menengah), dan RPS. Dari ketiga macam rencana perencanaan sarana dan prasarana tersebut merupakan rincian perencanaan dana untuk kedepannya, misalnya SD Islam Mohammad Hatta memiliki masterplan dengan menggunakan analisis lingkungan yakni menjadikan sekolah agar menjadi lebih rindang dengan penanam beberapa pohon, dari situ upaya yang dilakukan di tahun pertama seperti pembelian pohon dan penanamannya, kemudian tahun kedua yakni rencana jangka menengah atau RJM telah menyelesaikan $25 \%$, sehingga di tahun keempat yakni RPS atau rencana program sekolah agar dapat berhasil menuju $100 \%$ dan menyelesaikan menjadi sekolah yang rindang sesuai dengan rencana awal.

\section{Dana operasional}

Adanya sebuah perencanaan yang tersusun dalam RKAS maka perlu sebuah dana sebagai bukti berjalannya sebuah program yang telah direncankan, dana operasional misalnya. Dana operasional adalah dana yang digunakan untuk keperluan dan kebaikan sekolah dan warga sekolah, yang berasal dari pemerintah pusat dan pemerintah daerah, serta dari masyarakat yang salah satunya dari wali murid SD Islam Mohammad Hatta. Dana operasional berasal dari:

a. Dari pemerintah pusat atau BOSNAS yang digunakan untuk operasional sekolah

b. Dari dana pemerintah daerah atau BOSDA

Dana BOS merupakan program pemerintah yang pada dasarnya adalah untuk penyediaan pendanaan biaya operasi nonpersonalia bagi satuan pendidikan dasar sebagai pelaksana program wajib belajar. ${ }^{32}$. Sebagaimana yang dilakukan oleh SD Islam Mohammad Hatta menggunakan dana BOS untuk keperluan operasional sekolah

${ }^{31}$ Komang Alit Wahyuni, "Efektivitas Rencana Kegiatan dan Anggaran Sekolah (RKAS) Pada Kualitas Layanan Pendidikan SMK dan SMA di Kecamatan Sawan Tahun Ajaran 2013/2014”, Vol. 4, No. 1, Hlm. 8.

${ }^{32}$ Muhammad Firyal Akbar, "Evaluasi Kebijakan Program Pemberian Dana Bantuan Oprasional Sekolah”, Junal Analisis Kebijakan dan Pelayanan Jasa Publik, Vol. 2, No. 1, 2016, Hlm. 3. 
misalnya pembelian ATK, perlengkapan untuk menunjang belajar mengajar misalnya meja, kursi, kipas angin dan alat yang membantu dalam kegiatan yang ada di sekolah. Sedangkan dalam masa ini masa pandemi covid 19 maka dana BOS yang awalnya untuk keperluan dan perawatan sarana dan prasarana harus diganti dengan adanya pembelian kamera, pembelian paket zoom untuk sistem pembelajaran online, dan penambahan sarana yang dibutuhkan ketika pandemi terjadi seperti pembelian alat cek suhu tubuh, penambahan kran untuk mengalirnya air ketika mencuci tangan, face shield, dan kebutuhan lainnya.

Sedangkan untuk perencanan dana yang lainnya yaitu berasal dari masyarakat yang dapat disebut dengan dana swadaya masyarakat.

3. Dana swadaya masyarakat

Dana swadaya masyarakat berasal dari masyarakat salah satunya dari wali murid, dana swadaya masyarakat terbagi menjadi 2 yakni DPP dan SPP:

DPP; adalah dana yang khusus untuk pembagunan sekolah dan pengembangan sumber daya manusia dalam hal ini meliputi profesional (masih akan diadakannya dana pendidikan dan dana pelatihan bagi karyawan) dan spritual (adanya program umroh bagi karyawan).

SPP; merupakan dana yang digunakan untuk honorium guru dan karyawan. SPP dibayarkan dari wali murid melaui tunai maupun non tunai setiap bulan.

Kendala yang dialami dalam penyusunan RKAS:

1. Mendatangkan komite, orang tua, serta SDM saat penyusunan RKAS.

Dalam penyusunan RKAS membutuh komite, orang tua dan SDM yang lainnya, namun dikarenakan saat ini masih pandemi covid-19 yang tidak diperkenankan untuk berkumpul dengan orang banyak maka terjadi kendala dalam penyusunan RKAS.

2. Beberapa item yang telah direncakan tidak seusai dengan kenyataan.

Keadaan yang direncakan tidak selalu dengan kenyataan, meskipun sudah diusahakan dengan perencanaan dengan baik, sebagaimana yang ada di SD Islam Mohammad Hatta telah merencakana RKAS dengan baik untuk satu tahun kedepan, namun dengan adanya pandemi covid-19 maka RKAS harus diubah dengan menyesuiakan keadaan agar tetap berjalan dengan baik.

3. Dana yang terlambat cair.

Sesuai dengan keadaan yang telah direncanakan maka dana juga harus siap untuk diimplementasikan, namun kendala yang terjadi apabila dana yang telambat cair dari pemerintah maka harus segera mencari solusi untuk menutupi kendala.

\section{PENUTUP}

Manajemen merupakan sebuah kegiatan untuk menjalankan sebuah program untuk mencapai tujuan bersama. Sebagaimana manajemen sarana dan prasarana yang memiliki susunan yakni perencanaan, pengadaan, pengaturan, penggunanaan dan penghapusan. Dalam hal ini penting untuk langkah awal yakni sebuah perencanaan. Perencanaan manajemen sarana dan prasarana perlu dilakukan sebagai langkah untuk sarana dan prasarana dapat berjalan dengan baik yang ada di SD Islam Mohammad Hatta. Perencanaan sarana dan prasarana memiliki proses ini yakni : Menganalisis kebutuhan sarana dan 
Leadership: Jurnal mahasiswa manajemen pendidikan Islam

ISSN (P): 2721-7108, ISSN (E): 2715-0399

Vol. 03 No. 01 bulan Desember 2021

prasarana yang ada dan Memproyeksi sarana dan prasarana yang dibutuhkan di masa depan. Hasil dari adanya proses inti yaitu adanya RKAS. RKAS ini memiliki perencanaan dengan jangka waktu tahun yang berbeda-beda. Namun adanya sebuah pandemi RKAS yang telah tersusun harus diubah sesuai kondisi yakni pandemi covid-19, dan pelaporan juga harus menyesuaikan kebutuhan sarana dan prasarana di masa pandemi covid-19.

\section{DAFTAR PUSTAKA}

Akbar, Muhammad Firyal. 2016. "Evaluasi Kebijakan Program Pemberian Dana Bantuan Oprasional Sekolah", Junal Analisis Kebijakan dan Pelayanan Jasa Publik, Vol. 2, No. 1.

Bancin, Aswin dan Wildansyah Lubis. 2017. Manajemen Sarana dan Prasarana Pendidikan, (Studi Kasus SMA Negeri 2 Lupuk Pakam), Educandu, Vol. 10,No. 1.

Barnawi dan M. Arifin. 2012. Manajemen Sarana dan Prasarana Sekolah (Jogjakarta: Ar-Ruzz Media,).

Eliot, E.B. and E.E. Mossier. 1945. "Organization of Planning for Education, dalam American education in the post War Period", NSSE (Chacago: Chicago Press)

Maryadi dan Nasrudin. 2018. "Manajemen Sarana Dan Prasarana Pendidikan dalam Pembelajaran di SD, Jurnal Managemen Pendidikan", Vol. 13, No. 1.

Maujud, Fathul. 2018. "Implementasi Fungsi-Fungsi Manajemen dalam Lembaga Pendidikan Islam (Studi Kasus Pengelolaan Madrasah Ibtidaiyah Islahul Muta'alim Pagutan)", Jurnal Penelitian Keislaman, Vol.14 No. 1.

Nurhattati dan Matin. 2017. "Manajemen Sarana dan Prasarana Pendidikan: Konsep dan Aplikasinya", (Depok: PT Rajagrafindo Persada).

Nurhikmahyanti, Desi "Manajemen Sarana Prasarana Pendidikan di SMA Negeri 1 Driyorejo Gresik".

Riadli, Mashur. Partisipasi Komite Sekolah Dalam Penyususna Rencana Kegiatan dan Anggaran Sekolah (RKAS) di SMA Se-Kabupaten Sleman

Saebani, Beni Ahmad. 2012. Filsafat Manajemen, (Bandung: Pustaka Setia).

Sahnan, Muhammad. 2017. Urgensi Perencanaan Pendidikan di Sekolah Dasar, Jurnal PPKn dan Hukum, Vol. 12 No. 2.

Sobri, Ahmad Yusuf. 2015. "Manajemen Pendidikan Karakter Berbasis Religi Di Sekolah Dasar". 24 No. 1.

Sri Setyaningih, "Pengelolaan Sarana Prasarana dalam Implementasi Kurikulum Pendidikan Guru Sekolah Dasar: Sebuah Studi Kasus di Universitas Negeri Semarang", Jurnal Managemen Pendidikan, Vol. 13, No. 1.

Susilawati, Iseu. dkk. 2016.Implementasi Fungsi Manajemen dalam Pelayanan Bimbingan Manasik haji di Kelompok Bimbingan Ibadah Haji, Tadbir: Jurnal Manajemen Dakwah, Vol. 1 No. 2.

Sylviani, Devi Dwi. 2018. "Kondisi Sarana dan Prasarana Pendidikan SMP Negeri Se-Kecamatan Pengasih Kabupaten Kulon Progo". 
Leadership: Jurnal mahasiswa manajemen pendidikan Islam

ISSN (P): 2721-7108, ISSN (E): 2715-0399

Vol. 03 No. 01 bulan Desember 2021

Tubagus Djaber Abeng Ellong, "Manajemen Sarana Dan Prasarana di Lembaga Pendidikan Islam, Jurnal Pendidikan Islam Iqra' ", Vol. 11. Nomor 1.

Wahyuni, Komang Alit. 2014. "Efektivitas Rencana Kegiatan Dan Anggaran Sekolah (Rkas) Pada Kualitas Layanan Pendidikan Smk dan Sma Di Kecamatan Sawan Tahun Ajaran 2013/2014", Vol. 4 No: 1.

Witanto, Janan. Bambang Ismanto, Wasitohadi. 2019. "Peningkatan Efektifitas Perencanaan Bantuan Operasional Sekolah Dalam Mendukung Kebutuhan Anggaran Berbasis Mutu Melalui Workshop Di Dabin lii Kecamatan Mojosongo Kabupaten Boyolali", Jurnal IImu Sosial dan Humaniora. Vol 8 No. 2. 